\title{
Extended low oxygen transmissibility contact lens use induces alterations in the concentration of proinflammatory cytokines, enzymes and electrolytes in tear fluid
}

\author{
LUIS FERNANDO BARBA GALLARDO ${ }^{1}$, MARTÍN HUMBERTO MUÑOZ ORTEGA ${ }^{2}$, \\ JAVIER VENTURA JUAREZ ${ }^{3}$, LISETH RUBÍ ALDABA MURUATO ${ }^{3}$, \\ ESPERANZA SÁNCHEZ ALEMÁN ${ }^{2}$, EDUARDO EMMANUEL VALDEZ MORALES ${ }^{4}$, \\ SUGELA SUSANA BLANCAS ZUGARAZO ${ }^{4}$ and JOSE RAFAEL VILLAFAN BERNAL ${ }^{4}$
}

\author{
${ }^{1}$ Optometry Department; ${ }^{2}$ Chemistry Department; ${ }^{3}$ Morphology Department; ${ }^{4}$ CONACYT-Department of Surgery \\ and Molecular Diagnosis Laboratory, Autonomous University of Aguascalientes, Aguascalientes 20131, Mexico
}

Received November 17, 2016; Accepted September 29, 2017

DOI: $10.3892 /$ etm.2018.5989

\begin{abstract}
Prolonged and continuous use of contact lenses for as long as 3 or 4 weeks is common in Mexico due to the low socioeconomic status, poor patient education and self-neglect. Furthermore, wearing contact lenses with low oxygen permeability is common due to their low cost. Thus, patients seek ophthalmologic evaluation due to signs and symptoms of overuse such as red eye, discomfort and tearing. In the present study, the effect of wearing soft contact lenses with a low oxygen permeability on the tear fluid composition after 1 day, 1 week and 1 month without removing them was examined. In this prospective clinical trial, several tear fluid biomarkers were measured in 84 non-adapted contact lens wearers (NACLWs), including the $\mathrm{pH}$, electrolytes, osmolarity, pro-inflammatory molecules [interleukin (IL)-8, IL-1 $\beta$ and interferon (IFN)- $\gamma$ ], total protein (TP) levels and enzymes [aspartate aminotransferase (AST), alanine aminotransferase (ALT), lactate dehydrogenase (LDH) and alkaline phosphatase (AP)]. The results indicated that the tear $\mathrm{pH}$ was significantly decreased after 1 day and 1 week; however, after 1 month of use, the tear $\mathrm{pH}$ level returned to the baseline. Tear electrolyte analysis demonstrated a significant decrease in $\mathrm{Na}^{+}$at 1 day, 1 week and 1 month and $\mathrm{Cl}^{-}$levels at 1 week and 1 month, and a significant increase in $\mathrm{Ca}^{2+}$ at 1 week and 1 month, $\mathrm{K}^{+}$at 1 day, 1 week and 1 month, IL- 8 at 1 week and 1 month, IL- $1 \beta$ only at 1 week and IFN- $\gamma$ at 1 week and 1 month. Furthermore, the
\end{abstract}

Correspondence to: Dr Jose Rafael Villafan Bernal, CONACYT-Department of Surgery and Molecular Diagnosis Laboratory, Autonomous University of Aguascalientes, 940 Av. Universidad, Ciudad Universitaria, Aguascalientes 20131, Mexico E-mail: joravibe@hotmail.com

Key words: extended contact lens wearers, cytokine, enzyme, tear fluid study observed an elevation of TP, AST, LDH and AP levels, however, there were no significant changes in ALT. In conclusion, the current study revealed that continuous wearing of soft contact lenses with low oxygen permeability increase tear fluid proinflammatory cytokine levels and enzymes reflecting tissue damage.

\section{Introduction}

The use of contact lenses has increased due to the various visual benefits they provide, including the convenience of not wearing glasses, the possibility of a fully corrected visual field and the total correction of refractive errors in cases of anisometropic amblyopia (1). Despite recent advances in lens composition materials that allow increased corneal oxygenation, the use of contact lenses with low oxygen transmissibility (low Dk/L) remains common in Mexico, since these lenses are markedly less expensive (2). Additionally, patients who wear lenses continuously without removing them overnight commonly seek consultation for various complaints, such as red eye, discomfort, tearing and reduced visual clarity (3).

There is evidence that contact lenses with low oxygen transmissibility limit the oxygen flow to the cornea $(4,5)$, thus increasing the production of lactic acid and decreasing the local $\mathrm{pH}(6,7)$. It has also been suggested that the continuous use of the contact lens induces an inflammatory response (8-10). The study by Thakur and Willcox (11) evaluated the alterations of proinflammatory cytokines levels in tear fluid induced by continuous contact lens use for 6 days in patients who developed contact lens-associated acute red eye or contact lens peripheral ulcer, and observed an elevation in interleukin (IL)-1 $\beta$ and interleukin 8 (IL-8) levels in these patients. By contrast, in NACLWs who wore soft lenses continually for $8 \mathrm{~h}$ (overnight) for the first time, a decrease in the concentrations of IL-8, leukotriene B4 and IL-6 was observed (12).

Although prolonged contact lens use is highly atypical in developed countries, the significance of the present study originates from the fact that the population investigated had various characteristics that made wearing contact lenses continuously 
for long periods a common habit, including a low socioeconomic status, poor patient education and self-neglect (13). To the best of our knowledge, there are currently no studies in the literature analyzing the alterations in the tear fluid composition induced subsequent to a month of continuous use of contact lenses. Therefore, the present study aimed to evaluate the effects of continuous contact lens use on the tear fluid composition after 1 day, 1 week and 1 month in NACLWs.

\section{Patients and methods}

Study design, patients and tear sample collection. The present prospective, nonrandomized clinical trial involved NACLWs who had continuously worn contact lenses (Soft Lens 59, Bausch \& Lomb, Rochester, New York, US) for the first time for the duration of 1 day, 1 week and 1 month and 21 non-contact lens users as a control group (age range, 18-23 years; mean age, 21.3 years; 11 males/10 females). NACLWs were assigned to one of 3 groups. In group $1(n=21$; age range 18-23 years; mean age 21.2 years; 10 males/11 females), patients continuously wore contact lenses for 1 day. In group $2(n=21$; age range 19-22 years; mean age 21.3 years; 10 males/11 females), patients continuously wore contact lenses for 1 week. In group 3 ( $n=21$; age range 17-22 years; mean age 21.4 years; 11 males/10 females), patients continuously wore contact lenses for 1 month.

All patients were evaluated by an ophthalmologist in the Department of Anterior Segment of the Didactic Medical Unit in the Autonomous University of Aguascalientes (Aguascalientes, Mexico) during the period January 2015 to December 2015.

Patients underwent slit-lamp examination to exclude any anterior segment condition, including conjunctivitis, blepharitis, keratitis and/or corneal ectasia. Dry eye was ruled-out in all patients using the Schirmer's test (HUB Pharmaceutical, LLC. Rancho Cucamonga, CA, USA), tear breakup time by Fluorescein Sodium Ophthalmic Strips Bio-Glo (HUB Pharmaceutical, LLC) and Lissamine ${ }^{\mathrm{TM}}$ green strips (HUB Pharmaceutical, LLC). All patients with systemic diseases (diabetes, hypertension, hepatic and/or autoimmune disease) were excluded.

Tear samples were collected at the end of the period contact lenses were worn for during a three-hour period (between 9:00 a.m. and 12:00 p.m.) from the lower tear meniscus without touching the eye or eyelids using a hand-directed $1 \mathrm{ml}$ BRAND $^{\circledR}$ pipette bulb (cat no. BR747775; Sigma-Aldrich; Merck KGaA, Darmstadt, Germany). In total, a sample of $100 \mu \mathrm{l}$ was obtained per collection. Immediately after collection, the samples were centrifuged at $14,000 \mathrm{x}$ g for $1 \mathrm{~min}$ at $4^{\circ} \mathrm{C}$ to remove cellular debris (Biorad Z216 MK; Siemensstraße, Wehingen, Germany) and stored at $-20^{\circ} \mathrm{C}$ for later processing.

Each patient provided written informed consent. All experiments were conducted according to the Declaration of Helsinki standards, and approved by the Medical Ethics Committee of the Autonomous University of Aguascalientes Research Division.

$p H$ determination. The tear fluid $\mathrm{pH}$ was determined by a colorimetric method (14) using bromothymol blue (3',3'-Dibromothymolsulfonphthalein; cat no. 114413;
Sigma-Aldrich; Merck KGaA) as an indicator, which has ionic activity in the $\mathrm{pH}$ range between 6.0 and 8.0. Color alterations occur as the $\mathrm{pH}$ increases or decreases, ranging from yellow at pH 6.0 to blue at pH 8.0 (Fig. 1).

Measurement of IL-8, IL-1 $\beta$ and interferon (IFN)- $\gamma$. Specific ELISA kits were employed to determine the tear levels of various proteins, including IFN- $\gamma$ (cat. no. 900-k27), IL-1 $\beta$ (cat. no. 900-k47.) and IL-8 (cat. no. 900-k18; all obtained from Peprotech, Inc., Rocky Hill, NJ, USA). Briefly, 96-well plates were coated with the primary antibody at a concentration of $0.5 \mu \mathrm{g} / \mathrm{ml}(1: 200)$ prior to being incubated overnight at room temperature. Following aspiration and washing (4 times) of wells $300 \mu$ l blocking buffer ( $1 \%$ bovine serum albumin in PBS) was then added and the plate was incubated for $1 \mathrm{~h}$. Following aspiration and washing, the standard solution or $10 \mu \mathrm{l}$ of tear sample was added to wells in duplicate and incubated for $2 \mathrm{~h}$. Then the plate was washed 4 times and the detection secondary antibody (biotinylated) at $0.5 \mu \mathrm{g} / \mathrm{ml}$ was added and incubated during $2 \mathrm{~h}$ at room temperature. After that, avidin peroxidase $(1: 2,000)$ from the same ELISA kit was added and incubated for $30 \mathrm{~min}$ at room temperature, followed by the addition of $100 \mu 1$ 2,2-azine-bis (3-ethylbenzothiazoline-6-sulfonic acid). The absorbance was subsequently measured at $415 \mathrm{~nm}$ with the wavelength correction set at $650 \mathrm{~nm}$ in an iMark ${ }^{\mathrm{TM}}$ microplate absorbance reader spectrophotometer (Bio-Rad Laboratories, Inc., Hercules, CA, USA). Finally, the cytokine levels were calculated by linear regression analysis.

Determination of enzymes, total protein (TP), electrolytes and osmolarity. To determine the concentrations of TP, $\operatorname{sodium}\left(\mathrm{Na}^{+}\right)$, chloride $\left(\mathrm{Cl}^{-}\right)$, potassium $\left(\mathrm{K}^{+}\right)$and calcium $\left(\mathrm{Ca}^{2+}\right)$, as well as the enzyme activity of aspartate aminotransferase (AST), alanine aminotransferase (ALT), alkaline phosphatase (AP) and lactate dehydrogenase (LDH) in the tear fluid, dry chemistry techniques were used. The analyses were performed using the automatized VITROS 5600 Immunodiagnostic system (Ortho Clinical Diagnostics, Raritan, NJ, USA). The following analytes were used: $309 \mathrm{Na}+$ Sodium, $307 \mathrm{Cl}$ - Chloride, $308 \mathrm{~K}+$ Potassium, $318 \mathrm{Ca}+$ Calcium 320, AST Aspartate Aminotransferase, 322 ALT Alanine Aminotransferase, 321 ALKP Alkaline Phosphatase, 323 LDH Lactate Dehydrogenase, according to the manufacturer's protocols. These equipment and reagents were approved by the Food and Drug Administration (Silver Spring, MD, USA). Briefly, the method for electrolytes quantitation was based on direct potentiometry $(\mathrm{Na}+, \mathrm{K}+, \mathrm{Cl}-)$ or colorimetry $(\mathrm{Ca}++)$. For $\mathrm{Na}+\mathrm{K}+$ and $\mathrm{Cl}-$ a drop of patient sample $(10 \mu \mathrm{l})$ and a drop of VITROS Reference Fluid $(10 \mu \mathrm{l})$ were collocated on separate halves of the slide resulting in migration of both fluids toward the center of the paper bridge. A stable liquid junction was formed that connected the reference electrode to the sample electrode. Each electrode produced an electrochemical potential in response to the activity of the ion. The potential difference between the two electrodes was proportional to the $\mathrm{Na}$, $\mathrm{K}+$ and $\mathrm{Cl}-$ concentration in the sample. For calcium, a drop of patient sample was deposited on the slide and was evenly distributed by spreading the layer to the underlying layers. The bound calcium was dissociated from binding proteins, allowing the calcium to penetrate through the spreading layer into the underlying reagent layer. There, the calcium formed a 


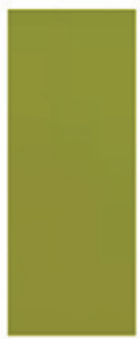

6.0

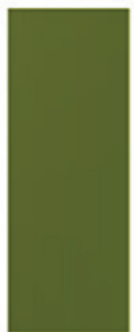

6.2

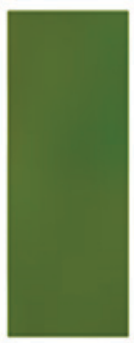

6.4

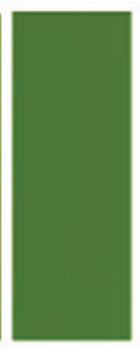

6.6

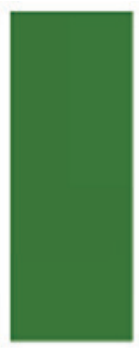

6.8

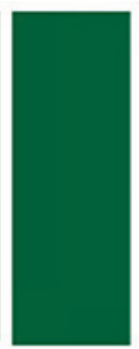

7.0

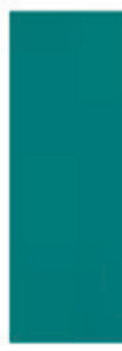

7.2

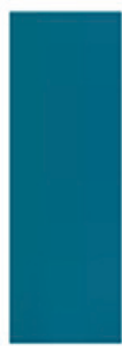

7.4

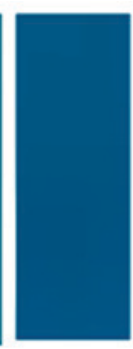

7.6

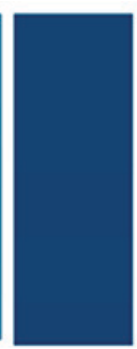

7.8

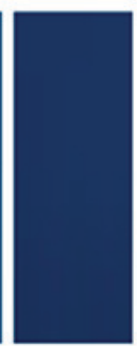

8.0
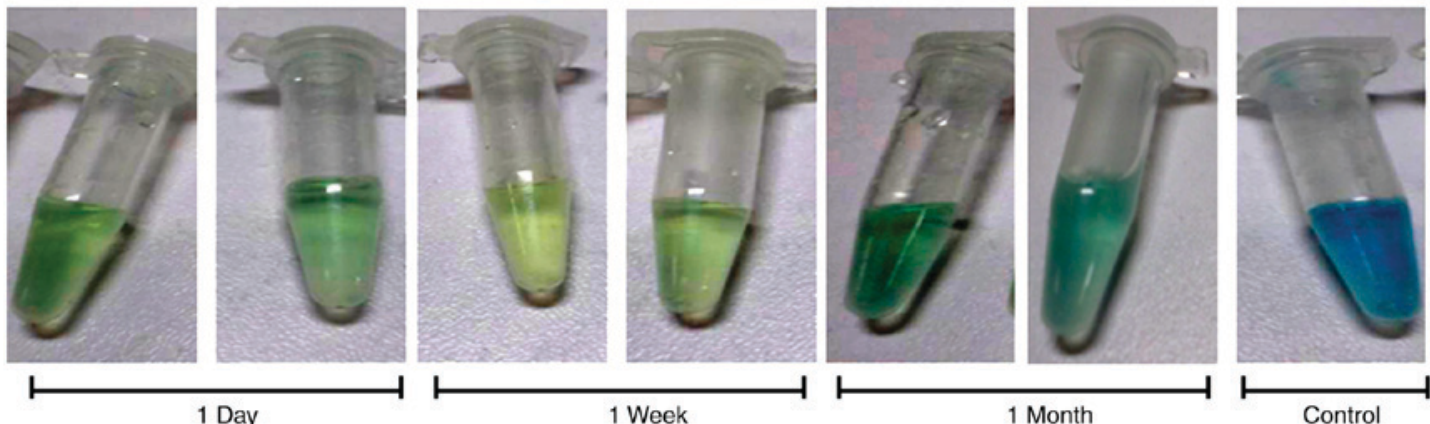

Control

Figure 1. Color scale in a pH range between 6.0 (yellow) and 8.00 (blue) using bromothymol blue in the controls and contact lenses users for 1 day, 1 week or 1 month continuously ( $\mathrm{n}=21$ each).

complex with Arsenazo III dye, causing a shift in the absorption maximum. Following incubation, the reflection density of the colored complex was measured spectrophotometrically with an automatized VITROS 5600 Immunodiagnostic system (Ortho Clinical Diagnostics, Raritan, NJ, USA). The amount of colored complex formed was proportional to the calcium concentration in the sample. Quantitation of ALT, AST, AP and LDH was performed by spectrophotometry (automatized VITROS 5600 Immunodiagnostic system; Ortho Clinical Diagnostics, Raritan, NJ, USA) in a test of multiple points where the rate of change in reflection density was proportional to enzyme activity at $340 \mathrm{~nm}$ (ALT and LDH), $670 \mathrm{~nm}$ (AST) or $400 \mathrm{~nm}$ (AP).

The osmolarity was calculated using the following formula: Osmolarity $(\mathrm{mOsm} / \mathrm{l})=2 \times\left(\mathrm{Na}^{+}+\mathrm{K}^{+}\right)$.

Statistical analysis. Statistical analysis and graphs were performed using the GraphPad Prism version 6.0 software (GraphPad Software, Inc., San Diego, CA, USA). Descriptive analysis data are reported as the mean \pm standard deviation. For inferential analysis, repeated measures analysis of variance and Dunnett's as post-hoc test were conducted. $\mathrm{P}<0.05$ was considered to indicate a statistically significant difference.

\section{Results}

Electrolyte levels. The tear concentration of $\mathrm{Cl}^{-}, \mathrm{Na}^{+}, \mathrm{K}^{+}$ and $\mathrm{Ca}^{2+}$ in NACLWs was analyzed in the present study (Table I; Fig. 2). A significant decrease was observed in the $\mathrm{Cl}^{-}$ tear levels following the first week of contact lens use, which was further decreased after 1 month when compared with the controls (Table I; Fig. 2). Similarly, the $\mathrm{Na}^{+}$concentration in the tear samples significantly decreased after 1 day of use with further decrements observed after 1 week and 1 month when compared with the control $\mathrm{Na}^{+}$concentration (Table I).
By contrast, the $\mathrm{K}^{+}$concentrations significantly increased after 1 day, further increasing after 1 week and 1 month when compared with the controls (Table I; Fig. 2). Similarly, the $\mathrm{Ca}^{2+}$ tear concentrations significantly increased after 1 week and 1 month of continuous lens use compared with those in the controls (Table I; Fig. 2). Furthermore, the osmolarity was significantly decreased after 1 week $(276.5 \pm 33.1 \mathrm{mOsm} / \mathrm{l})$ and 1 month $(260.6 \pm 20.7 \mathrm{mOsm} / \mathrm{l})$ of continuous contact lens use compared with that in the control group $(343.5 \pm 13.2 \mathrm{mOsm} / \mathrm{l}$; $\mathrm{P}<0.001$; Fig. 3A).

TP levels. The present study assessed whether there were any variations in the TP tear concentration in patients wearing contact lenses continuously (Fig. 3B). The results detected a significant increase in the TP levels $(1.56 \pm 0.04 \mathrm{~g} / \mathrm{dl}$; $\mathrm{P}<0.01)$ after 1 day, with the highest increase observed after 1 week $(2.45 \pm 0.05 \mathrm{~g} / \mathrm{dl} ; \mathrm{P}<0.0001)$ when compared with the controls $(1.38 \pm 0.05 \mathrm{~g} / \mathrm{dl}$; Fig. 3B). However, after 1 month of contact lens use, the TP levels $(0.38 \pm 0.02 \mathrm{~g} / \mathrm{dl})$ decreased even beyond those observed in the control group $(\mathrm{P}<0.0001$; Fig. 3B).

Tissue-damage enzymes. The present study results observed a marked increase in the ALT tear concentrations after the first day $(35.9 \pm 6.3 \mathrm{IU} / \mathrm{l})$, which remained high after 1 week (34.2 $\pm 7.4 \mathrm{IU} / \mathrm{l})$ and 1 month $(36.8 \pm 4.3 \mathrm{IU} / \mathrm{l})$ of continuous lens use, when compared with the control group (3.7 $\pm 5.6 \mathrm{IU} / \mathrm{l}$; $\mathrm{P}<0.0001$; Fig. 4A). However, no significant differences were observed in AST tear levels after 1 day, 1 week and 1 month when compared with the controls (Fig. 4B; P>0.05). By contrast, the AP levels were evidently increased after 1 day of continuous use $(90.7 \pm 18.7 \mathrm{IU} / 1)$, remaining similarly high after 1 week $(98.62 \pm 6.7 \mathrm{IU} / \mathrm{l})$ and further increasing after 1 month (243.8 $\pm 16.5 \mathrm{IU} / \mathrm{l})$, as compared with the AP concentration in the controls (58.5 $\pm 10.6 \mathrm{IU} / 1 ; \mathrm{P}<0.0001 ;$ Fig. 4C). Furthermore, 
Table I. Electrolyte levels in tear fluid.

\begin{tabular}{lcccc}
\hline Electrolyte & Control $[\mathrm{mEq} / \mathrm{l}]$ & 1 day $[\mathrm{mEq} / \mathrm{l}]$ & 1 week $[\mathrm{mEq} / \mathrm{l}]$ & $1 \mathrm{month}[\mathrm{mEq} / \mathrm{l}]$ \\
\hline $\mathrm{Cl}^{-}$ & $111.3 \pm 1.9$ & $110.2 \pm 1.0$ & $89.71 \pm 1.9$ & $56.62 \pm 1.3^{\mathrm{c}}$ \\
$\mathrm{Na}^{+}$ & $147.9 \pm 1.5$ & $136.2 \pm 3.8^{\mathrm{a}}$ & $103.5 \pm 3.5^{\mathrm{c}}$ & $63.96 \pm 1.7^{\mathrm{c}}$ \\
$\mathrm{K}^{+}$ & $23.06 \pm 0.64$ & $28.02 \pm 1.5^{\mathrm{b}}$ & $34.00 \pm 0.74^{\mathrm{c}}$ & $62.74 \pm 1.5^{\mathrm{c}}$ \\
$\mathrm{Ca}^{2+}$ & $0.91 \pm 0.06$ & $1.09 \pm 0.07$ & $1.71 \pm 0.08$ & $1.86 \pm 0.11$
\end{tabular}

1-Way ANOVA (Dunnett's multiple comparisons test ${ }^{\mathrm{a}} \mathrm{P}<0.05^{\mathrm{b}} \mathrm{P}<0.01^{\mathrm{c}} \mathrm{P}<0.0001$ ).
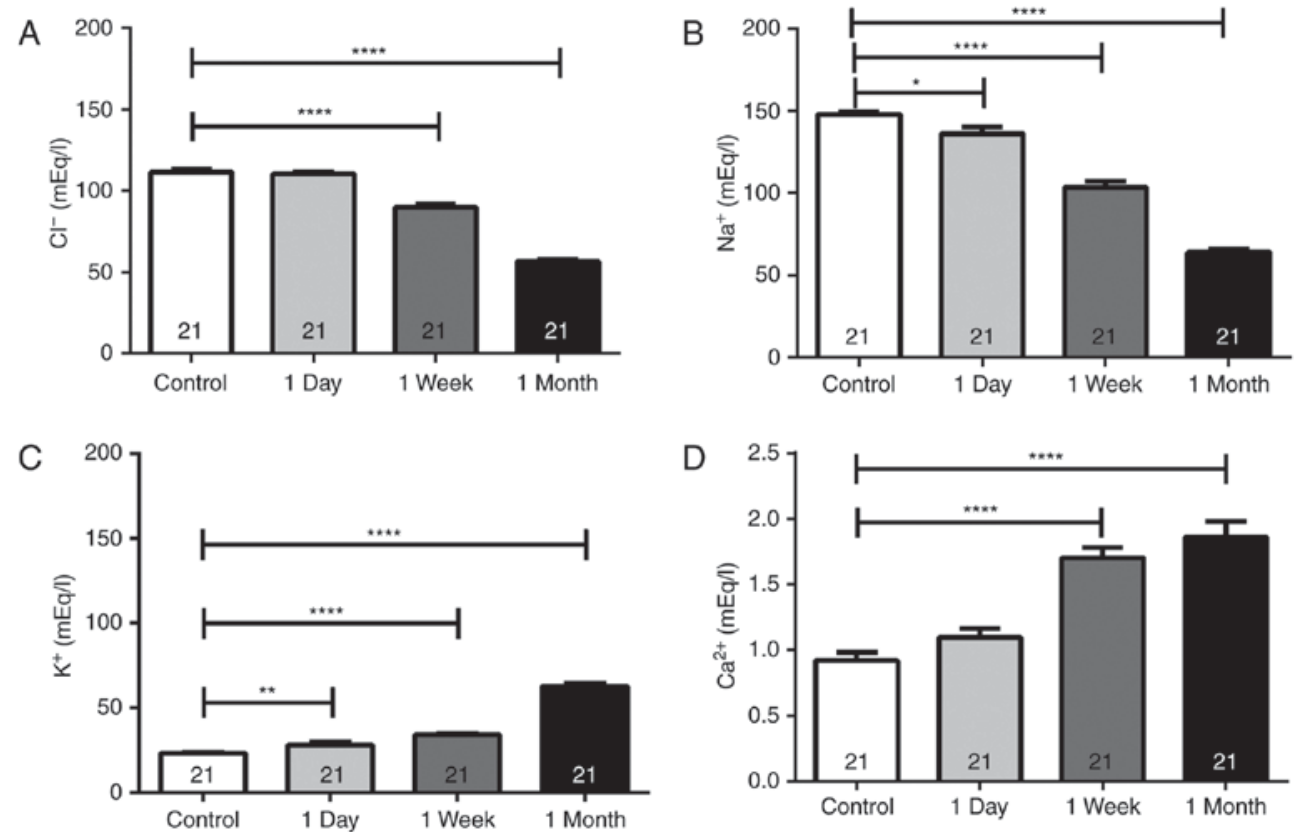

Figure 2. Tear electrolyte (A) $\mathrm{Cl}^{-}$, (B) $\mathrm{Na}^{+},(\mathrm{C}) \mathrm{K}^{+}$and (D) $\mathrm{Ca}^{+2}$ levels at 1 day, 1 week and 1 month of continuous contact lens use (n=21 each). ${ }^{*} \mathrm{P}<0.05$, ${ }^{* *} \mathrm{P}<0.01$ and ${ }^{* * * * *} \mathrm{P}<0.0001$.
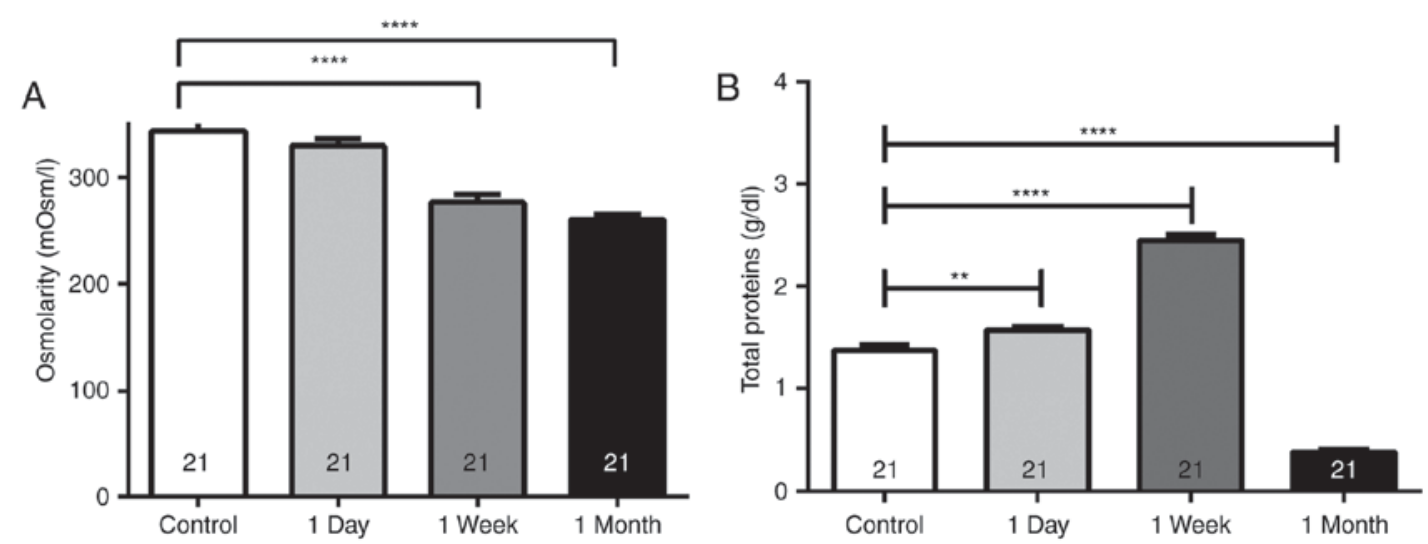

Figure 3. (A) Osmolarity and (B) total protein levels in tear samples obtained after 1 day, 1 week and 1 month of continuous contact lens use (n=21 each). ${ }^{* *} \mathrm{P}<0.01$ and ${ }^{* * * * *} \mathrm{P}<0.0001$.

the LDH tear levels were analyzed, and an increase was detected after 1 day $(310.1 \pm 21.2 \mathrm{IU} / 1)$ that continued similarly high after 1 week $(270.3 \pm 51.6$ IU/1) and peaked after 1 month $(359.6 \pm 21.1 \mathrm{IU} / \mathrm{l})$ when compared to controls ([LDH] $=210.9 \pm 12.7$ IU/1; P<0.0001; Fig. 4D).
Pro-inflammatory mediators $I L-8, I L-1 \beta$ and IFN- $\gamma$. A significant increase was observed in the IL-1 $\beta$ level after 1 day of continuous contact lens use $(0.38 \pm 0.09 \mathrm{ng} / \mathrm{ml})$ when compared with the controls $(0.07 \pm 0.04 \mathrm{ng} / \mathrm{ml} ; \mathrm{P}<0.01$; Fig. $5 \mathrm{~A})$. However, after 1 week $(0.12 \pm 0.07 \mathrm{ng} / \mathrm{ml})$ and 1 month $(0.07 \pm 0.04 \mathrm{ng} / \mathrm{ml})$, 

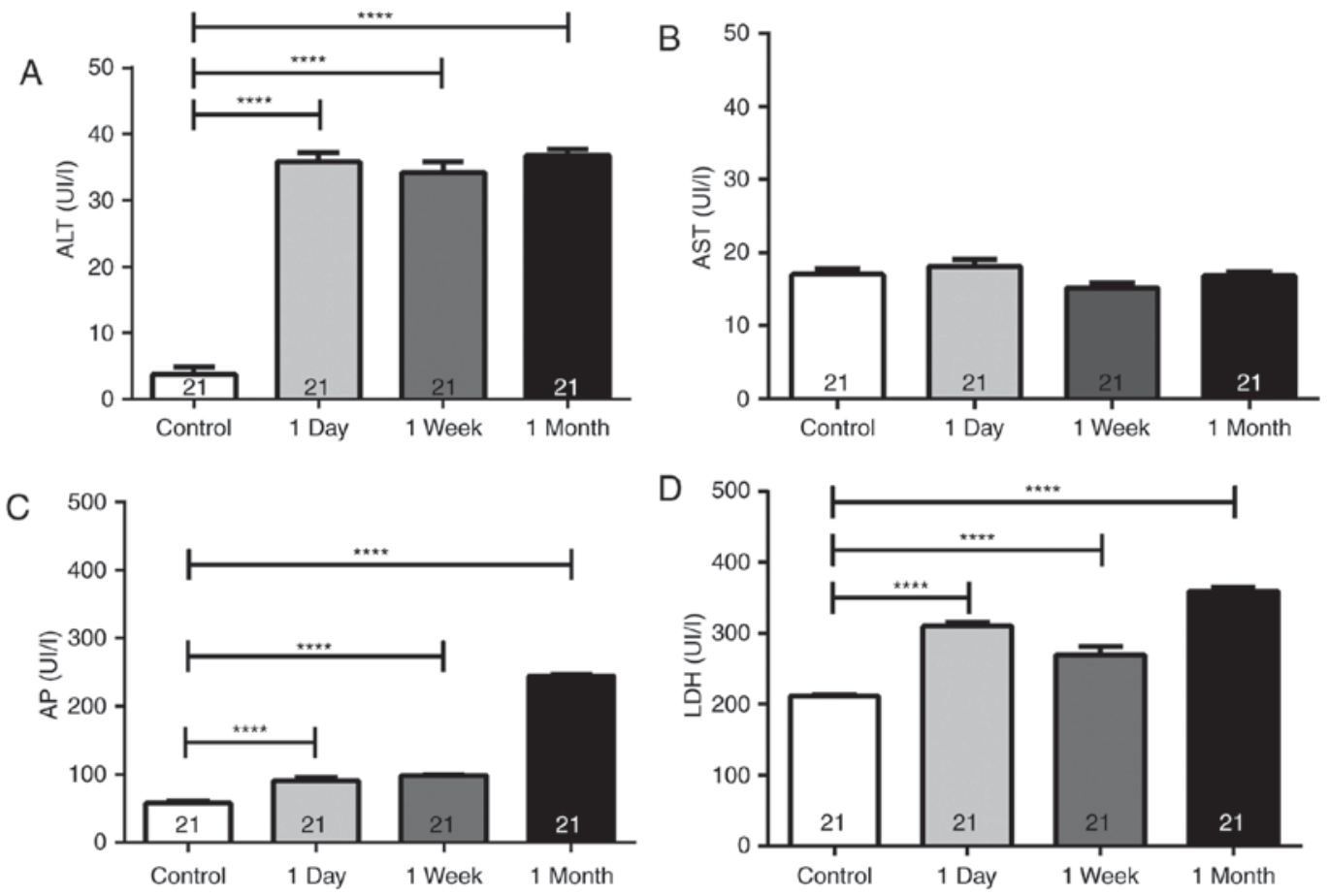

Figure 4. Tissue damage enzyme (A) ALT, (B) AST, (C) AP and (D) LDH levels after 1 day, 1 week and 1 month of continuous contact lens use (n=21 each). ${ }^{* * * * *} \mathrm{P}<0.0001$. ALT, alanine aminotransferase; AST, aspartate aminotransferase; AP, alkaline phosphatase; LDH, lactate dehydrogenase.
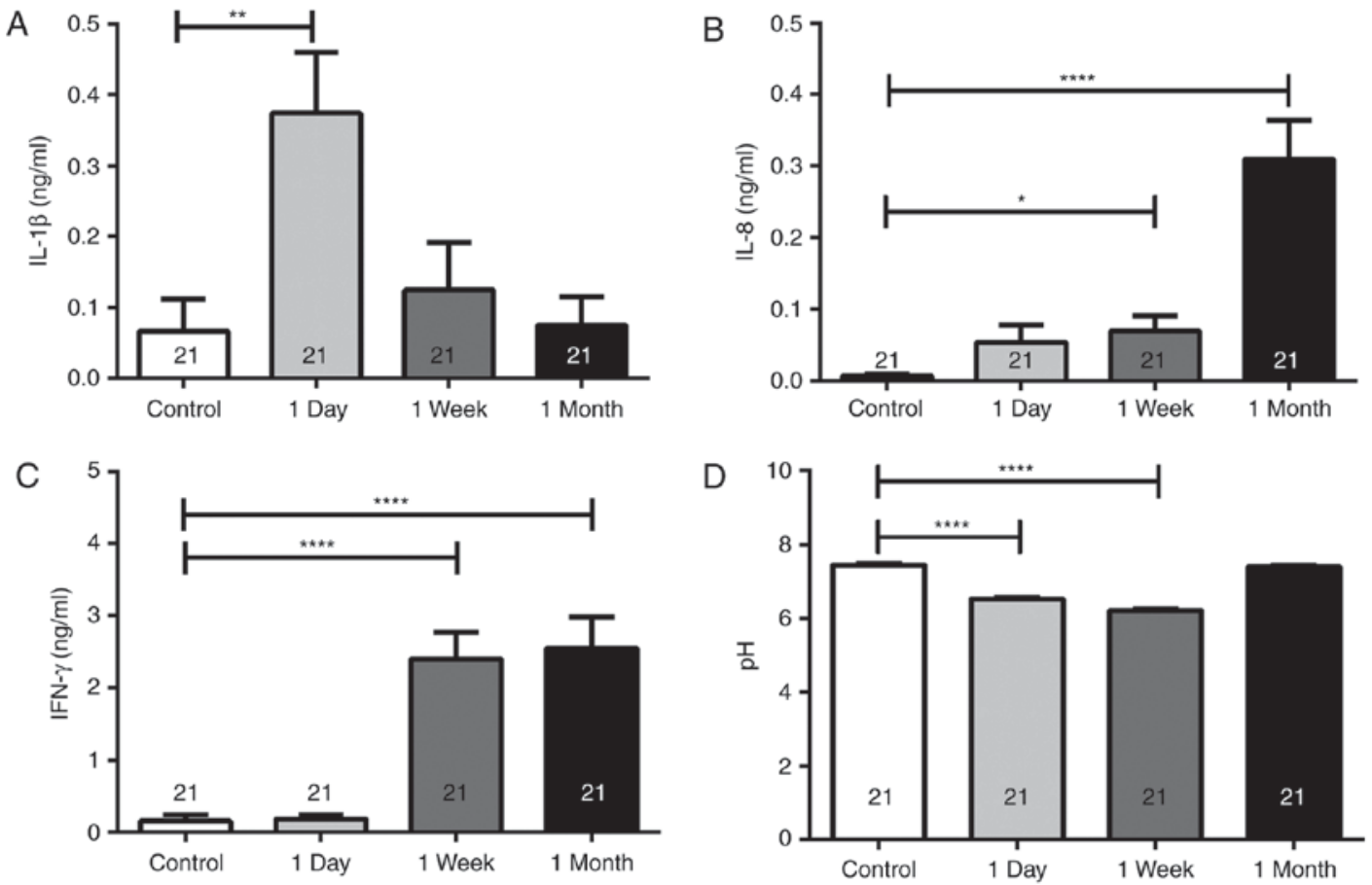

Figure 5. Proinflammatory cytokines levels (A) IL-1 $\beta$, (B) IL-8 and (C) IFN- $\gamma$ levels, as well as (D) pH values in the tear samples obtained after 1 day, 1 week and 1 month of continuous contact lens use ( $\mathrm{n}=21$ each). ${ }^{*} \mathrm{P}<0.05,{ }^{* *} \mathrm{P}<0.01$ and ${ }^{* * * * *} \mathrm{P}<0.0001$. IL, interleukin; IFN, interferon.

the IL-1 $\beta$ tear levels returned to the normal values (Fig. 5A). By contrast, IL-8 concentration began to increase significantly after 1 week $(0.07 \pm 0.02 \mathrm{ng} / \mathrm{ml} ; \mathrm{P}<0.05)$, reaching the highest level after 1 month $(0.31 \pm 0.05 \mathrm{ng} / \mathrm{ml} ; \mathrm{P}<0.0001)$, as compared with the controls $(0.007 \pm 0.003 \mathrm{ng} / \mathrm{ml}$; Fig. 5B). Furthermore, IFN- $\gamma$ levels were significantly increased after 1 week of continuous contact lens use $(2.40 \pm 0.37 \mathrm{ng} / \mathrm{ml})$ and sustained after 1 month $(2.55 \pm 0.43 \mathrm{ng} / \mathrm{ml})$ when compared with the control group (0.16 $\pm 0.09 \mathrm{ng} / \mathrm{ml}$; $\mathrm{P}<0.0001$; Fig. 5C).

Changes in tear $\mathrm{pH}$. The tear $\mathrm{pH}$ was significantly decreased after 1 day $(6.53 \pm 0.04)$, and 1 week $(6.22 \pm 0.032)$ of continuous use when compared with that in the controls $(7.44 \pm 0.034$; $\mathrm{P}<0.0001$; Fig. 5D). The tear $\mathrm{pH}$ after 1 month of contact lens 
use $(7.40 \pm 0.035)$ was returned to levels like those obtained in the control group (Fig. 5D).

\section{Discussion}

Although continuously wearing contact lenses for prolonged periods of time (such as for 1 month) is highly unadvisable, this is practiced by several patients (15). This habit is a result of various factors, including low income, poor patient education and self-neglect (16). The present study investigated several biochemical and immunological alterations associated with the continuous use of contact lenses in NACLWs. Certain of these changes persisted throughout the evaluated month, although other parameters were altered over the first week and then returned to the basal levels, indicating a possible adaptation of the local tissue to the use of contact lenses. An example of this adaptation was the change in tear fluid $\mathrm{pH}$, which decreased after 1 day and 1 week of continuous contact lens use and returned to the basal levels after 1 month. However, other parameters, including IL-8, IFN- $\gamma$ and LDH, remained altered at all the evaluated time points. This may be associated with a sustained damaging effect of contact lenses in the micro-environment of the cornea and neighboring tissues.

The increase of IL-1 $\beta$ levels after 1 day of continuous use and its subsequent return to basal levels at 1 week, along with the increase of IL- 8 and IFN- $\gamma$ after 1 week and 1 month, observed in the present study may indicate an uninterrupted inflammatory state. This may be generated by the friction between the lens and the corneal surface plus the hypoxia induced by the low Dk/L lenses. In fact, it has been suggested that friction in the presence of corneal hypoxia induces a blood flow increase, as well as limbal and bulbar redness, and triggers an inflammatory response $(6,17,18)$.

The IL-8 elevation in the tear fluid detected after 1 week and 1 month of continuous contact lens wearing in the present study may be associated with the preceding elevation of IL-1 $\beta$ (observed after 1 day), since it has been previously demonstrated that IL-1 $\beta$ promotes the release of IL- 8 in the human corneal epithelial cells (19). However, the sustained elevation of IFN- $\gamma$ in the contact lens wearers may be damaging since this cytokine antagonizes IL-13, a molecule involved in the differentiation of goblet cells and mucin production (20). Additionally, IFN- $\gamma$ also promotes apoptosis and squamous metaplasia of the epithelia of the cornea and bulbar conjunctiva (20). The findings of the current study regarding the IFN- $\gamma$ levels warrant further investigation since, to the best of our knowledge, there is no substantial research on the IFN- $\gamma$ tear levels in contact lens wearers with continuous use for prolonged periods of time. Kehinde et al (21) reported no clear trends in the IFN- $\gamma$ profile during 30 days of continuous use of contact lenses.

The elevation of tissue damage enzymes (LDH, AP, AST and ALT) in tears may also be associated with the combined effect of mechanical friction (caused by the lid rubbing against the contact lens, which results in direct tissue damage) and the hypoxia induced by the low oxygen transmissibility lenses. Metabolic enzymes, such as LDH, AP, AST and ALT, have been detected in the tear fluid of healthy patients at levels similar to those observed in the serum (22-24). However, only a limited number of studies have reported findings regarding the effect of contact lenses on tissue damage-associated enzyme levels. For instance, Tözsér and Berta (25) demonstrated higher LDH levels in the tear fluid samples from patients with mechanical conjunctivitis when compared with those from viral conjunctivitis or bullous keratitis patients. However, there are no other studies on the effect of contact lens use on AST, ALT or AP tear levels. Since the LDH isoform present in tears is different than the one found in the serum (26), the elevated levels detected in the tear samples of the NACLW population in the present study may be the result of a detrimental effect of contact lenses on the anterior eye and contiguous tissues.

According to the present study findings, it is suggested that low oxygen transmissibility (due to the lens composition and characteristics) and the friction of the lens with the anterior ocular surface are the causes of the observed alterations in the cytokines and enzymes levels in tear fluid.

In conclusion, the current study demonstrated an increase in the inflammatory cytokine levels and tissue damage enzymes, along with variations in the $\mathrm{pH}$, osmolarity and electrolytes, in Mexican patients that continuously wore low Dk/L contact lenses for 1 month. Therefore, it is important to strongly advise against the continuous use of contact lenses with low oxygen transmissibility, or to select a lens material with a higher Dk/L and to frequently remove the contact lenses. Although the present study inferred that the tear fluid biomarkers will return to the basal levels after discontinuing the use of the contact lenses, a subsequent study with serial biomarker measurement following this discontinuation would be required to verify this.

\section{References}

1. Sulley A, Young G, Lorenz KO and Hunt C: Clinical evaluation of fitting toric soft contact lenses to current non-users. Ophthalmic Physiol Opt 33: 94-103, 2013.

2. Morgan PB, Woods CA, Tranoudis IG, Helland M, Efron N, Carrillo Orihuela G, Grupcheva CN, Jones D, Tan KO, Pesinova A, et al: International contact lens prescribing in 2012. Contact Lens Spectrum 28: 31-38, 2013.

3. López Alemán A and Serés Revés C: Uso prolongado de lentes de contacto. Edicions Ulleye. Xàtiva Spain, pp. 21-27, 2003.

4. Fatt I, Weissman BA and Ruben CM: Areal differences in oxygen supply to a cornea wearing an optically powered hydrogel contact lens. CLAO J 19: 226-234, 1993.

5. Fatt I and Weissman BA: Influence of polarographic cathode diameter on measured oxygen transmissibility of hydrogel contact lenses with optical power. Optom Vis Sci 69: 931-935, 1992.

6. Stapleton F, Ramachandran L, Sweeney DF, Rao G and Holden BA: Altered conjunctival response after contact lens-related corneal inflammation. Cornea 22: 443-447, 2003.

7. Klyce SD: Stromal lactate accumulation can account for corneal oedema osmotically following epithelial hypoxia in the rabbit. J Physiol 321: 49-64, 1981.

8. Cubitt CL, Tang Q, Monteiro CA, Lausch RN and Oakes JE: IL-8 gene expression in cultures of human corneal epithelial cells and keratocytes. Invest Ophthalmol Vis Sci 11: 3199-3206, 1993.

9. Cubitt CL, Lausch RN and Oakes JE: Differences in interleukin-6 gene expression between cultured human corneal epithelial cells and keratocytes. Invest Ophthalmol Vis Sci 36: 330-336, 1995.

10. González-Pérez J, Villa-Collar C, Moreiras T, Gesto I, González-Méijome JM, Rodríguez-Ares MT and Parafita M: Tear film inflammatory mediators during continuous wear of contact lenses and corneal refractive therapy. Br J Ophthalmol 96: 1092-1098, 2012

11. Thakur A and Willcox MD: Cytokine and lipid inflammatory mediator profile of human tears during contact lens associated inflammatory diseases. Exp Eye Res 67: 9-19, 1998.

12. Thakur A and Willcox MD: Contact lens wear alters the production of certain inflammatory mediators in tears. Exp Eye Res 70: $255-259,2000$ 
13. Loh KY and Agarwal P: Contact lens related corneal ulcer. Malays Fam Physician 5: 6-8, 2010.

14. Norn MS: Hydrogen ion concentration of tear fluid. Estimated on the basis of a bromothymol-blue-dyed lacrimal streak. Acta Ophthalmol (Copenh) 46: 189-200, 1968.

15. Nesburn AB: Ophthalmology-epitomes of progress: Continuous wear contact lenses. West J Med 128: 432-433, 1978.

16. Morales Mac-Hale C: Compliance with contact lenses in Latin America: An educational, not a cultural challenge. Cienc Tecnol Salud Vis Ocul 13: 113-125, 2015.

17. Efron N: Contact lens-induced changes in the anterior eye as observed in vivo with the confocal microscope. Prog Retin Eye Res 26: 398-436, 2007.

18. Yüksel Elgin C, İskeleli G, Talaz S and Akyol S: Comparative analysis of tear film levels of inflammatory mediators in contact lens users. Curr Eye Res 4: 441-447, 2016.

19. Cavet ME, Harrington KL, Vollmer TR, Ward KW and Zhang JZ: Anti-inflammatory and anti-oxidative effects of the green tea polyphenol epigallocatechin gallate in human corneal epithelial cells. Mol Vis 17: 533-542, 2011.

20. Pflugfelder SC, Corrales RM and de Paiva CS: T helper cytokines in dry eye disease. Exp Eye Res 117: 118-125, 2013.
21. Kehinde LE, Elder KS and Fullard RJ: Effects of daily vs. 30 day continuous contact lens wear on tear cytokine levels. Invest Ophthalmol Vis Sci 50: 5656, 2009.

22. Ananthi S, Santhosh RS, Nila MV, Prajna NV, Lalitha P and Dharmalingam K: Comparative proteomics of human male and female tears by two-dimensional electrophoresis. Exp Eye Res 92: 454-463, 2011

23. Sariri R and Ghafoori $\mathrm{H}$ : Tear proteins in health, disease and contact lens wear. Biochemistry (Mosc) 73: 381-392, 2008.

24. Zhou L, Zhao SZ, Koh SK, Chen L, Vaz C, Tanavde V, Li XR and Beuerman RW: In-depth analysis of the human tear proteome. J Proteomics 75: 3877-3885, 2012.

25. Tözsér $\mathbf{J}$ and Berta A: Lactate dehydrogenase activity in pathological human tears obtained with glass capillaries correlates with the albumin content. Int Ophthalmol 22: 289-292, 1998.

26. van Haeringen NJ and Glasius E: Enzymes of energy-producing metabolism in human tear fluid. Exp Eye Res 18: 407-409, 1974.

This work is licensed under a Creative Commons Attribution-NonCommercial-NoDerivatives 4.0 International (CC BY-NC-ND 4.0) License. 